\title{
Phytochemical Screening and Antimicrobial Effect of Ethanolic Leaf Extract of Alstonia boonei De Wild (Apocynaceae) on some Selected Pathogenic Micro-organisms
}

\author{
J.O. Arogbodo* \\ Microbiology Division, Department of Animal Production and Health, Federal University of \\ Technology, Akure, Ondo State, Nigeria \\ *Corresponding author
}

\section{A B S T R A C T}

\section{Keywords}

Alstonia boonei, Antibiotics, Microorganisms, Inhibition zones, Phytochemicals

Article Info

Accepted:

12 June 2019

Available Online:

10 July 2019
Antibiotics usage in animal production has been restricted by World Health Organization (WHO) due to their negative effects leading to the development of antibiotics resistant bacteria (superbugs) in animals and humans. The search for alternatives to antibiotic growth promoters has led to various researches in phytomedicine. An in-vitro experiment was therefore conducted to evaluate the antibacterial effect of ethanolic leaf extract of Alstonia boonei De Wild (Apocynaceae) on the following selected bacterial isolates: Escherichia coli, Salmonella typhi, Proteus mirabilis, Staphylococcus aureus and Pseudomonas aeruginosa. The antimicrobial effect was performed by agar well diffusion method. Preliminary phytochemical screening of the extract of Alstonia boonei indicated the presence of tannins, cardiac glycosides, flavonoids, saponnins, steroids and terpenoids while phlobatannins and anthraquinones were absent. The extract produced significant inhibitory effect on $S$. aureus and $P$. aeruginosa with inhibition zones of $19 \mathrm{~mm}$, $16 \mathrm{~mm}$, Minimum Inhibitory Concentration (MIC) of $6.25 \mathrm{mg} / \mathrm{ml}$ and $12.50 \mathrm{mg} / \mathrm{ml}$ respectively. E. coli, S. typhi and $P$. mirabilis were not sensitive to the extract. It was concluded that Staphylococcus aureus and Pseudomonas aeruginosa were highly sensitive to ethanolic leaf extract of Alstonia boonei.

\section{Introduction}

Sequel to the restriction of antibiotics as growth promoters in animal husbandry by the World Health Organization due to emergence and the spread of antibiotic-resistant germs (WHO, 2016). Plants have become a ready, dependable and inexhaustible alternative to antibiotic growth promoters (AGP) in animal production; ruminant animals inclusive (Bamikole et al., 2019). Probiotics, synbiotics and diet-acidifiers can also be used as alternatives to AGP (Faluyi et al., 2017, Biwas et al., 2018 and Widya et al., 2019). Interestingly plants over the years have been utilized by traditional medical practitioners in the treatment of various ailments. This may be due to their inherent bio-safety and relative 
low cost (Hui, et al., 2009). These plants have now become a veritable source of modern medicines (Cragg and Newman, 2005). A good example of modern medicine from medicinal plants is Mama Powder® antimalaria drug manufactured by Drug Research and Production Unit of Obafemi Awolowo University Ile-Ife (OAU) from Alstonia boonei and Picralima nitida. Alstonia boonei (Apocynaceae) as reported by Owolabi et al., (2014) is a plant indigenous to Nigeria and locally used for treating diabetes mellitus.

The plant is called "ahun" in Yoruba, "Ogbuora" in Igbo and "Ukhu" in Urhobo (Majekodunmi, et al., 2008). It was reported by John-Prosper et al., (2012) that the bark/leaves of Alstonia boonei possess antirheumatic, anti-inflammatory, analgesic, antimalaria, antipyretic, anti-diabetic, anthelmintic and antimicrobial prorperties. The ethanolic leaf extract of Alstonia boonei has the potential to reduce low density cholesterol, increase high density cholesterol as well as high density lipoprotein in Rats (Owolabi, et al., 2014). According to Olayinka and Vera, (2015) ethanolic leaf extract of Alstonia boonei possess intrinsic antiplasmodial activity with the ability to suppress parasite growth. Antimicrobial activities of plant extracts against pathogenic microorganisms have been reported by some researchers: Ajetunmobi and Towolawi (2014) reported the positive antibacterial activity of aqueous and ethanolic leaf extract of Chrysophyllum albidum on Escherichia coli, Salmonella typhi, Staphylococcus aureus, Corynebacterium and Candida albicans with inhibition zones ranging from $37 \mathrm{~mm}-45 \mathrm{~mm}$. According to Ubandoma et al., (2018), ethanolic extract of the stem bark of Vitex doniana has antibacterial effect against Pseudomonas aeuruginosa. This experiment therefore was conducted and focused majorly on the phytochemical screening and antimicrobial effect of ethanolic leaf extract of
Alstonia boonei De Wild (Apocynaceae) on some selected pathogenic microorganisms.

\section{Materials and Methods}

\section{Collection of plant material}

The leaves of Alstonia boonei used in this experiment were harvested from the forest located in the environment of The Federal University of Technology Akure, Ondo State in the month of February 2017 and properly identified in the Department of Forestry and Wood Technology of the same University. The fresh leaves were gently rinsed in distilled water and shade dried for two weeks to prevent photolysis of the inherent phytochemicals (Thakare, 2004). The leaves were thereafter ground into powder in a Thomas Willey® grinding machine. The homogenized powder of the sample was preserved in an air-tight plastic container until usage.

\section{Preparation of the extract}

$500 \mathrm{~g}$ of the powdered leaves was soaked into five litres $(5000 \mathrm{ml})$ of $80 \%$ ethanol to be in the ratio of $1: 10(\mathrm{w} / \mathrm{v})$ for effective phytochemicals' extraction. The mixture was kept for 72hours in a tightly sealed plastic container at room temperature and stirred thrice daily using a sterile glass rod. At the expiration of the 72 hours, filtration was done with muslin cloth and re-filtered with Whatman filter paper No $1(125 \mathrm{~mm})$. The wet extract was later concentrated by exposure to a flat aluminium tray under fan. Recovered extract was weighed and divided into two parts for phytochemical screening and bacteria susceptibility test.

\section{Percentage yield}

Yield from the extract was calculated and expressed in percentage as follows; Weight of 
container $=20.10 \mathrm{~g}$, Container + extract $=$ $79.69 \mathrm{~g}$, Yield $=59.69 \mathrm{~g}$, Quantity of powdered leaves soaked $=500 \mathrm{~g} . \%$ yield $=\frac{59.69}{500} \times 100$. Percentage yield $=11.94 \%$

\section{Phytochemical screening of the extract}

Phytochemical screening was carried out on the plant sample by adopting the standard procedure described by Banu and Catherine (2015) to confirm the presence of tannins, saponins, phlobatannins, cardiac glycosides, steroids, terpenoids, anthraquinones and flavonoids.

\section{Test organisms}

Clinical strain of Escherichia coli, Salmonella typhi, Proteus mirabilis, Staphylococcus aureus and Pseudomonas aeruginosa were obtained from the Microbiology Department of a reputable Private Hospital in Akure, Ondo State, Nigeria. The organisms were carefully maintained on nutrient slants at $4^{0} \mathrm{C}$.

\section{Standardization of test organisms}

Sub-culturing of the bacterial isolates was done onto Mueller Hinton Agar (MHA) plates and incubated at the temperature of $37^{\circ} \mathrm{C}$ for 24 hours following the procedure described by Olaseinde et al., (2016) to meet McFarland standard $\left(10^{6} \mathrm{cfu} / \mathrm{ml}\right)$.

\section{Standardization of plant extract}

The extract was reconstituted by adding $1 \mathrm{~g}$ of the extract to $3 \mathrm{ml}$ of DMSO (Dimethylsulphoxide) and $7 \mathrm{ml}$ of sterile distilled water to get the concentration of $100 \mathrm{mg} / \mathrm{ml}$ as the stock solution.

Six-fold serial dilution was done to obtain six different concentrations of $100 \mathrm{mg} / \mathrm{ml}$, $50 \mathrm{mg} / \mathrm{ml}, 25 \mathrm{mg} / \mathrm{ml}, 12.50 \mathrm{mg} / \mathrm{ml}, 6.25 \mathrm{mg} / \mathrm{ml}$ and $3.13 \mathrm{mg} / \mathrm{ml}$.

\section{Antimicrobial activity of the extract}

Antimicrobial activity of the extract was determined using agar well diffusion method as described by Thitilertdecha et al., (2008) following standard aseptic microbiological methods throughout the experimental period. Seventeen (17) sterile petri-plates were used for this experiment. One petri-plate was prepared per organism and done in triplicates. Two were left for positive test control.

Agar was prepared by adding $12 \mathrm{~g}$ of Mueller Hinton Agar (MHA) into 300ml of distilled water according to manufacturer's recommendation. Autoclaving at $121{ }^{\circ} \mathrm{C}$ (15 lbs pressure) for 15 minutes was done. The prepared agar was cooled down before being poured into the prepared seventeen petri-plates and allowed to set. Sterilized $4 \mathrm{~mm}$ borer was used in boring seven equidistant wells: wells 1 - 6 for different concentrations of extract $(3.13 \mathrm{mg} / \mathrm{ml}-100 \mathrm{mg} / \mathrm{ml})$ while well 7 was meant for the solvent (DMSO 30\%) as control. The last two plates for antibiotic sensitivity test were not bored. With the aid of sterile swabbing stick, a dip of each of the microbial inoculum was spread on the agar plate per organism.

$60 \mu \mathrm{L}$ of the extract at set concentration was introduced to each of the wells with the aid of a micro pipette. Maxi discs (made by Maxicare Medical Laboratory ${ }^{\circledR}$ ) for gram negative and gram positive organisms were gently laid on the remaining two plates. The plates were allowed to rest undisturbed on the laboratory bench for 45 minutes for proper prediffusion of the extract before incubation at $37^{\circ} \mathrm{C}$ for 24 hours as described by Osuntokun (2015). The zones of inhibition were measured using transparent $15 \mathrm{~cm}$ metre rule and taken as antimicrobial activity of the extract. The activity of solvent (DMSO 30\%) was determined and no antimicrobial activity against the test organisms was observed. 


\section{Minimum Inhibitory Concentration (MICs)}

The Minimum Inhibitory Concentrations (MICs) of the ethanolic leaf extract of Alstonia boonei were determined from the concentrations of the zones of inhibition.

\section{Results and Discussion}

The preliminary phytochemical screening of the extract of Alstonia boonei indicated the presence of tannins, cardiac glycosides, flavonoids, saponnins, steroids and terpenoids while phlobatannins and anthraquinones were absent as presented in Table 1. The results of the antimicrobial effects are shown in Table 2, 3 and 4.

Ethanolic leaf extract of Alstonia boonei as analysed in this study showed the presence of tannins, cardiac glycosides, flavonoids, saponnins, steroids and terpenoids. Phlobatannins and anthraquinones were absent (Table 1). The presence of saponins, cardiac glycosides, flavonoids etc. agrees with ethanolic leaf extract and ethanolic root extract of A. boonei reported by Owolabi et al., (2014), Francis and Osei, (2015) respectively. Antimicrobial results as shown in Table 2 and 3 showed that ethanolic leaf extract of A. boonei has high effectiveness against $S$. aureus and $P$. aeruginosa with the maximum inhibition zones of $19 \mathrm{~mm}$ and $16 \mathrm{~mm}$ respectively. The MIC for $S$. aureus was $6.25 \mathrm{mg} / \mathrm{ml}$ while that of $P$. aeruginosa was $12.5 \mathrm{mg} / \mathrm{ml}$. This antimicrobial property is in line with Kokkaiah et al., (2017) who reported high effect of the leaf extract of $A$. boonei against $S$. aureus, E. coli and $P$. aeruginosa (though with different solvents). Likewise, Francis and Osei (2015) reported the positive antimicrobial activity of the ethanolic root extract of Alstonia boonei against S. aureus, Bacillus subtilis, Candida, $P$. aeruginosa, and E. coli. The antimicrobial activity could be attributed to the available phytochemicals in the extract (Lavanya et al., 2016). However, Escherichia coli, Salmonella typhi and Proteus mirabilis were not sensitive to the various concentrations of the extract prepared in this study. This observation was also reported by Ali et al., (2017) with methanolic leaf extract of $A$. boonei to possess no antimicrobial activity against $S$. aureus, $S$. typhi and Klebsiella pneumonia. $P$. aeruginosa was resistant to all the commercial antibiotics used as positive control while on the contrary S. aureus was sensitive to all the commercial antibiotics as shown in Table 4. The high resistance of $P$. aeruginosa in this experiment agrees with Hugo and Rusell (1998), that $P$. aeruginosa has gained a reputation as the most resistant of the gram negative organisms.

Table.1 Qualitative Phytochemical screening of ethanolic leaf extract of Alstonia boonei

\begin{tabular}{|l|l|}
\hline Phytochemicals & Alstonia boonei \\
\hline Tannins & + \\
\hline Saponins & + \\
\hline Phlobatannins & - \\
\hline Cardiac Glycosides & + \\
\hline Steroids & + \\
\hline Terpenoids & + \\
\hline Anthraquinones & - \\
\hline Flavonoids & + \\
\hline
\end{tabular}

Where $(+)=$ present and $(-)=$ absent 
Table.2 Mean zones of Inhibition (mm) of ethanolic leaf extract of Alstonia boonei on bacterial isolates

\begin{tabular}{|c|c|c|c|c|c|c|c|}
\hline \multirow{2}{*}{$\begin{array}{l}\text { Bacterial } \\
\text { isolates }\end{array}$} & \multicolumn{6}{|c|}{ Mean zones of inhibition (mm) } & \multirow{2}{*}{$\begin{array}{l}\text { DMSO } \\
\text { 30\% }\end{array}$} \\
\hline & $\begin{array}{l}100 \\
(\mathrm{mg} / \mathrm{ml})\end{array}$ & $\begin{array}{l}50 \\
(\mathrm{mg} / \mathrm{ml})\end{array}$ & $\begin{array}{l}25 \\
(\mathrm{mg} / \mathrm{ml})\end{array}$ & $\begin{array}{l}12.50 \\
(\mathrm{mg} / \mathrm{ml})\end{array}$ & $\begin{array}{l}6.25 \\
(\mathrm{mg} / \mathrm{ml})\end{array}$ & $\begin{array}{l}3.13 \\
(\mathrm{mg} / \mathrm{ml})\end{array}$ & \\
\hline EC & 00 & 00 & 00 & 00 & 00 & 00 & 00 \\
\hline ST & 00 & 00 & 00 & 00 & 00 & 00 & 00 \\
\hline PM & 00 & 00 & 00 & 00 & 00 & 00 & 00 \\
\hline SA & 19 & 17 & 15 & 12 & 06 & 00 & 00 \\
\hline PA & 16 & 15 & 13 & 07 & 00 & 00 & 00 \\
\hline
\end{tabular}

Where EC= Escherichia coli, $\mathrm{ST}=$ Salmonella typhi, $\mathrm{PM}=$ Proteus mirabilis, $\mathrm{ST}=$ Staphylococcus aureus and $\mathrm{PA}=$ Pseudomonas aeruginosa

Table.3 Minimum Inhibitory Concentrations (MICs) of the ethanolic leaf extract of Alstonia boonei on bacterial isolates

\begin{tabular}{|l|l|l|l|l|l|}
\hline \multirow{2}{*}{$\begin{array}{l}\text { MICs } \\
(\mathbf{m g} / \mathbf{m l})\end{array}$} & \multicolumn{5}{|c|}{ Bacterial Isolates } \\
\cline { 2 - 6 } & EC & ST & PM & SA & PA \\
\cline { 2 - 7 } & 00 & 00 & 00 & 6.25 & 12.5 \\
\hline
\end{tabular}

Where EC $=$ Escherichia coli, $\mathrm{ST}=$ Salmonella typhi, $\mathrm{PM}=$ Proteus mirabilis, $\mathrm{SA}=$ Staphylococcus aureus and $\mathrm{PA}=$ Pseudomonas aeruginosa

Table.4 Antibiotic sensitivity test for tested bacterial isolates

\begin{tabular}{|c|c|c|c|c|c|c|}
\hline \multirow{2}{*}{$\begin{array}{l}\text { Commercial } \\
\text { antibiotics }\end{array}$} & \multicolumn{4}{|c|}{ Bacterial isolates (Gram -tive) } & \multirow{2}{*}{$\begin{array}{l}\text { Commercial } \\
\text { antibiotics }\end{array}$} & \multirow{2}{*}{$\begin{array}{c}\text { S. A (Gram } \\
\text { +ive) }\end{array}$} \\
\hline & S. $T$ & P. A & E. $C$ & P. $M$ & & \\
\hline Septrin & $\mathrm{R}$ & $\mathrm{R}$ & 26 & 26 & Pefloxacin & 26 \\
\hline Chloramphenicol & 25 & $\mathrm{R}$ & 20 & 30 & Gentamycin & 18 \\
\hline Sparfloxacin & 26 & $\mathrm{R}$ & 30 & 30 & Ampiclox & 22 \\
\hline Ciprofloxacin & 30 & $\mathrm{R}$ & 32 & 30 & Zinnacef & 25 \\
\hline Amoxicillin & 20 & $\mathrm{R}$ & $\mathrm{R}$ & 28 & Amoxicillin & 20 \\
\hline Augmentin & $\mathrm{R}$ & $\mathrm{R}$ & $\mathrm{R}$ & 22 & Rocephin & 25 \\
\hline Gentamycin & 20 & $\mathrm{R}$ & 25 & 24 & Ciprofloxacin & 30 \\
\hline Pefloxacin & 26 & $\mathrm{R}$ & 26 & 28 & Streptomycin & 22 \\
\hline Tarivid & $\mathrm{R}$ & $\mathrm{R}$ & $\mathrm{R}$ & $\mathrm{R}$ & Septrin & 25 \\
\hline Streptomycin & 15 & $\mathrm{R}$ & 24 & $\mathrm{R}$ & Erythromycin & 24 \\
\hline
\end{tabular}

Where Conc $=$ Concentration of the extract, $\mathrm{R}=$ Resistant, $\mathrm{IZ}=$ Inhibition zone, $\mathrm{P} . \mathrm{M} .=$ Proteus mirabilis, $\mathrm{P} . \mathrm{A} .=$ Pseudomonas aeruginosa, S.A. = Staphylococcus aureus, S.T. $=$ Salmonella typhimurium, E.C. $=$ Escherichia coli. tive $=$ negative and + tive $=$ positive 
However, this organism was highly sensitive to the ethanolic leaf extract of $A$. boonei with inhibition zone of $16 \mathrm{~mm}$ showing that the extract used was highly efficacious against the organism.

It therefore will be a futile exercise to adopt the usage of commercial antibiotics (experimented here) in the treatment of disease caused by $P$. aeruginosa.

In conclusion, ethanolic leaf extract of Alstonia boonei demonstrated high antimicrobial effect against Staphylococcus aureus and Pseudomonas aeruginosa but none against Escherichia coli, Salmonella typhi and Proteus mirabilis. Further research could be done on this plant to isolate the bioactive element(s) responsible for the antimicrobial property.

This will be highly priceless to pharmaceutical industries in the formulation of herbal antimicrobials for treating those diseases caused by microorganisms sensitive to the extract of plant(s) concerned. Trials with other solvents for possible better antimicrobial performance could also be explored.

\section{References}

Ajetunmobi, A. O. and Towolawi, G. A. (2014). Phytochemical Analysis and Antimicrobial Effect of Chrysophyllum albidum Leaf Extract on Gastrointestinal Tract Pathogenic Bacteria and Fungi in Human. Journal of Applied Chemistry (IOSR JAC). e-ISSN: 2278 - 5736. Volume 7, Issue 1 ver. II. (Feb., 2014), PP 01- 05.

Ali, F. U., Orinya, O. F., Ominyi, M. C., Ezenwali, M. O., Onwe, L. C., Nwacheta, C., Aliegbere, A., Akpan, M. S., Nwhite, O. M., Onuigbo, G. N and Onuigbo, C.A. I. (2017). Assessment of Antibacterial Activities Crude Leaf Extracts of Selected Medicinal Plants from Ezza North Ebonyi State Nigeria Against Staphylococcus aureus, Klebsiella pneumonia, Pseudomonas aeruginosa, Escherichia coli and Streptococcus Mutans. International Journal of Pharmaceutical Science Invention. 6(9): $13-18$.

Bamidele, M. A., Babayemi, O. J., Lamidi, A. A., Ayinde, B. A., Ikhatua, U. J., Ojeaga, S., Ezemba, T and Alatia, O. (2019). Preliminary in vitro screening of some spices and medicinal plants from Edo and Rivers State, Nigeria for reducing enteric methane production in ruminants. Nig. J. Anim. Prod. 2019, 46(2): 258 - 268

Banu, S. K and Catherine, L. (2015). General Techniques Involved in Phytochemical Analysis. International Journal of Advanced Research in Chemical Science (IJARCS). 2(4): April, 2015 pp 25 - 32.

Biwas, A., Junaid, N., Kumawat, M., Qureshi, S. and mandal, A B. (2018): Influence of Dietary Supplementaion of Probiotics on Intestinal Histomorphometry, Blood Chemistry and Gut Health Status of Broiler Chickens. South African Journal of Animal Science. 48 (5): 967-976.

Cragg, G. and Newman, D. J. (2005). Biodiversity: a continuing source of novel drugs leads. Pure and Applied Chemistry. 2005; 77(1): 7 - 24.

Faluyi, O. B., Arogbodo, J. O. and Adebayo, I. A. (2017). Growth performance and immunological responses of broiler chickens fed synbiotics and diet-acidifiers to Newcastle Disease vaccinations. Trop. Vet. 35(1) 11- 20.

Francis, O. and Osei, A. (2015). Antimicrobial and Phytochemical Properties of Alstonia boonei Extracts. Organic Chemistry Current Research 2015, 4: (1) pp 137 140.

Hugo, W. B and Russell, A. D. (1998). Pharmaceutical Microbiology, $6^{\text {th }}$ Edition Black well Science Ltd. Osney Mead oxford OX2 25 John Street, London WCIN $6 \mathrm{AJ}$

Hui, H., Tang, G and Go, V. L. W. (2009). Hypoglycemic herbs and their action mechanisms. Chin. Med. 4:11 - 14.

John-Prosper, K. A., Adukpo, G. E., Boahen, Y. O and Armah, F. A. (2012). A review of the Ethnobotany and Pharmacological 
Importance of Alstonia boonei De Wild (Apocynaceae). Article ID 587160. Pp 1 9.

Kokkaiah, I., Sethupandian, G and Palanichamy, M. (2017). Antimicrobial activity of selected Indian Folk medicinal plants: Myristica fatua, Alstonia boonei, Helictress isora, Vitex altissima and Atalantia racemosa. Asian Journal of Pharmaceutical and Clinical Research. 10(2): 277 - 280.

Lafanya, J., Selvam, S., Priya, M., Jacintha, P and Aradana, M. (2016). Antioxidant and antimicrobial activity of selected Medicinal plants against human oral pathogens. Int. J. Pharm Sci. 2016; 8: 9 pp 277 - 280.

Majekodunmi, F., Takeda, Y., Yamashit, H., Okabe, H and Yamauchi, T. (2008). New cucurbitane triterpenoids from Mormordica charantia. J. Nat. Prod. 53(6):1491- 1497.

Olaseinde, G. I., Okolie, Z. V., Oniha, M. I., Adekeye, B. T and Ajayi, A. A. (2016). In vitro antibacterial and antifungal activities of Chrysophyllum albidum and Diospyros monbuttensis leaves. Journal of Pharmacognosy and Pyhtotherapy. 8(1): 17.

Olayinka, F. O. and Vera, M. (2015). In vivo Activity of Ethanolic Extract of Alstonia Boonei Leaves against Plasmodium berghei in Mice. Journal for Worldwide Holistic Sustainable Development. 4(1): 60 - 68.

Osuntokun, O. T. (2015). Comparative Study of Antibacterial and Phytochemical Properties of Nigerian Medicinal Plants on Salmonella bongori and Salmonella enteritidis isolated from Poultry Faeces in Owo Local Government. Ondo State, Nigeria. Archives of current research international. 2(1): 1 11.
Owolabi, O. J., Arhewoh, I. M., Innih, S. O., Anaka, O. N and Monyei, C. F. (2014). The Ethanol Leaf Extract of Alstonia boonei (Apocynaceae) Reduces Hyperglycemia in Alloxan-Induced Diabetic Rats. Nigerian Journal of Pharmaceutical Sciences. 13(1): $12-21$.

Thakare, M. (2004). Pharmacological sreeening of some medicinal plants as antimicrobial and feed additive. Masters' Thesis. Department of Animal and Poultry Science, Virginia Polytechnic Institute and State University, Blackburg, Virginia, USA.

Thitilertdecha, N., Teerawutgulrag, $\mathrm{A}$ and Rakariyatham, N. (2008). Antioxidant and antibacterial activities of Nephelium lappaceum L. extracts. LWT-Food Science and Technology. 2008; 41(10): 2029- 2035.

Ubandoma, A., Imarenezor, E. P. K., Brown, S. T. C., Tatah, S. V., Simon, S and Ebuara, F. U. (2018). Antibacterial Activity of Leaves and Stem Bark Extracts of Vitex doniana on Pseudomonas aeruginosa. International Journal of Microbiology and Application 2018; 5(3): $64-69$.

WHO (2016). "Antibiotic resistance". World Health Organization, Archived from the original on 20 April 2016. Retrieved from Wikimedia on 28 March, 2019.

Widya, P. L., Teguh, B. P., Anam, A. A., Soeharsono, S., Sri, H., Nenny, H., Rifgy, N., Khoirul, H., Hana, C. P. W., Nabil, F. N. R and Andreas, B. Y. (2019). Potency of probiotics Bifidobacterium spp and Lactobacillus casei to improve growth performance and business analysis in organic laying hens. Veterinary World. 12(21): $860-867$.

\section{How to cite this article:}

Arogbodo, J.O. 2019. Phytochemical Screening and Antimicrobial Effect of Ethanolic Leaf Extract of Alstonia boonei De Wild (Apocynaceae) on some Selected Pathogenic Microorganisms. Int.J.Curr.Microbiol.App.Sci. 8(07): 1373-1379.

doi: https://doi.org/10.20546/ijcmas.2019.807.164 